Indonesian Journal of Global Health Research

Volume 3 Number 1, February 2021, pp. 43 - 50

e-ISSN 2715-1972; p-ISSN 2714-9749

http://jurnal.globalhealthsciencegroup.com/index.php/IJGHR

\title{
ROM THERAPY ON MUSCLE STRENGTH IN POST STROKE PATIENTS: SCOPING REVIEW
}

\author{
Muliyani Yamlean ${ }^{1}$, Chandra Bagus Ropyanto ${ }^{2}$, Fitria Handayani \\ ${ }^{1}$ Department of Nursing, Faculty of Medicine, Universitas Diponegoro, Jl. Prof Soedarto, Tembalang, \\ Kec. Tembalang, Semarang, Central Java, Indonesia 50275 \\ ${ }^{2}$ Adult Nursing Division, Department of Nursing, Faculty of Medicine, Universitas Diponegoro, J1. Prof \\ Soedarto, Tembalang, Tembalang Sub-District, Semarang, Central Java, Indonesia 50275 \\ *aliabubaker85.j1@gmail.com
}

\begin{abstract}
Hemiparesis and hemiplegia are motor deficits found mostly in stroke patients. If the deterioration in muscle strength that occurs is not handled properly, it will cause permanent disability. ROM therapy is a therapy to increase muscle strength which has undergone various developments according to the research that has been done. The aim of this article was to identify interventions using ROM therapy to improve muscle strength in post-stroke patients. The databases used were JCS, PMC, Science Direct, and PubMed. The search was limited to articles published in 2014 to 2019. The study criteria was for adult, quantitative comparisons between before and after intervention ROM therapy and full text article, published in peer-reviewed journal and written in English and Indonesian. This article used the methodological framework by Arksey and O'Malley for the scoping review. The research has conducted a study of 4 articles, in which all of the items discussed the application of ROM therapy to increase muscle strength in post-stroke patients. The results from each articles showed that ROM therapy has helped improve muscle strength in post-stroke patients.
\end{abstract}

Keywords: muscle strength; post stroke; ROM

\begin{tabular}{|c|c|c|c|}
\hline $\begin{array}{c}\text { First Received } \\
12 \text { December } 2020\end{array}$ & $\begin{array}{c}\text { Revised } \\
\text { 15 December } 2020\end{array}$ & $\begin{array}{c}\text { Accepted } \\
28 \text { December } 2020\end{array}$ & \\
\hline $\begin{array}{c}\text { Final Proof Received } \\
\text { 03 January } 2021\end{array}$ & & $\begin{array}{c}\text { Published } \\
\text { 01 February } 2021 \\
\end{array}$ & \\
\hline $\begin{array}{l}\text { How to cite (in APA style) } \\
\text { Yamlean, M., Ropyanto, C., \& Handayani } \\
\text { Patients: Scoping Review. Indonesian } \\
\text { https://doi.org/10.37287/ijghr.v3i1.314 }\end{array}$ & $\begin{array}{l}\text { F. (2021). ROM Therapy } \\
\text { Journal of Global }\end{array}$ & $\begin{array}{l}\text { on Muscle Strength in Post } \\
\text { Health Research, 3(1), }\end{array}$ & $\begin{array}{l}\text { Stroke } \\
43-50 .\end{array}$ \\
\hline
\end{tabular}

\section{INTRODUCTION}

Stroke is a cause of long-term disability in adults. Approximately $10 \%$ of stroke patients who live ultimately recover without experiencing disabilities, $25 \%$ recover with slight disabilities, $40 \%$ have moderate to severe disabilities that require long-term care. Post-stroke disabilities include impaired mobilization, self-care, cognitive ability communication, socialization, and emotional disturbances (National E-Health Transition Authority, 2012).

World Health Organization (WHO) data shows that there were 13.7 million new stroke cases every year, and about 5.5 million deaths occurred due to stroke (Kemenkes RI, 2018). The data showed that Indonesia is currently the country with the largest number of stroke sufferers in Asia and globally. Basic Health Research data in 2018 showed the prevalence of stroke sufferers reached 10.9 percent of the population suffering from strokes, and around $2.5 \%$ died while the rest had mild to severe disabilities (Kementerian Kesehatan RI Badan Penelitian dan Pengembangan, 2018). The prevalence of stroke in Central Java itself in 2018 was higher than the national one, which reached 11 percent. The proportion was third place for noncommunicable diseases after heart disease and diabetes mellitus with 3.09\% (Jateng, n.d.). Based on the data from the Semarang City Health Profile, there were 670 cases of stroke in 
2015 for haemorrhagic stroke and 1,215 cases for non-haemorrhagic stroke (Profil Kesehatan Kota Semarang, 2016).

The impact of a stroke in the form of hemiparesis and hemiplegia is a form of motor deficit. According to Winstein et al. 1, 2016 a conducted form of the motor deficit is caused by impaired motor neurons characterized by loss of control of voluntary movements, movement disorders, limited muscle tone, and limited reflexes. Post-stroke disabilities include impaired mobilization, self-care, communication, cognitive abilities, socialization, and emotional disorders. Return of perfusion of blood to brain tissue is essential for the recovery of normal brain function (National E-Health Transition Authority, 2012). However, blood flow return can also lead to more progressive brain damage, leading to further tissue dysfunction and infarction, leading to further disability (Husna et al., 2015).

Decreased muscle strength in stroke patients causes immobilization or the inability to move the body. Complications due to immobilization that are not appropriately handled are abnormal tone, orthostatic hypotension, deep vein thrombosis, and contractures (Garrison, 2003). Contractures are one of the effects of paralysis left untreated, resulting in loss or incomplete range of motion due to fibrosis of the muscle and skin supporting tissue. Contractures can cause functional disorders, impaired mobilization, disruption of daily activities, and incurable disabilities, especially after an ischemic stroke. Blood vessel blockage has occurred for a long time and slowly (Asmadi, 2012).

Post-stroke patients have an impact on muscle weakness. Based on the previous research (Susanti et al., 2019) and (Kristiani, 2017), muscle strength in stroke patients found that the scale decreased muscle strength to a scale of 4.3 to 2 . This decrease occurs because nerve cells are irreversibly damaged and will eventually experience dysfunction. The brain nerve cell dysfunction's location and magnitude will determine the type of neurological deficit that occurs. Neurological deficits may include motor dysfunction and sensory deficits. The most common motor dysfunction is hemiplegia, which is the paralysis or motor function weakness on one side. This motor function weakness can be caused due to the rupture of brain blood vessels and lesions in the brain's motor function, resulting in a neurological deficit on the opposite side (Nurbaeni et al., 2010).

Stroke patients need rehabilitation to minimize physical disabilities so that they can carry out normal activities (National E-Health Transition Authority, 2012). Joint movement exercise or $\mathrm{ROM}$ is one of the programs to improve patients' function with stroke. ROM is an exercise to maintain or enhance the ability to move the joints naturally to increase muscle mass and muscle tone and stimulate because the more motor units involved, the increase in muscle strength will also increase the ability to mobilize post-stroke patients (Bakara \& Warsito, 2016). The results of the study (Anggriani et al., 2018) found that ROM therapy increases the hand and leg muscle strength of respondents with an average hand muscle strength before 2.5 to 3.52. Based on this background, this scoping review aimed to identify the use of ROM therapy to improve muscle strength in post-stroke patients.

\section{METHOD}

This article used the methodological framework proposed by Arksey and O'Malley for scoping reviews. Five steps must be taken, including identifying the research question clearly and objectively, identifying relevant articles, selecting related literature from articles and data extraction, organizing, summarizing, analysing, and reporting the data results. The problem in this article was, "How can ROM therapy improve muscle strength in post-stroke patients?". 
Tabel 1.

The inclusion criteria of the study

\begin{tabular}{ll}
\hline & Inclusion criteria \\
\hline Period & Maximum issuance period of 10 years (2010-2020) \\
Study Type & Experiment \\
Language & English and Indonesian \\
Journal type & The original research article, full text available \\
Journal Contents Theme & Range of motion, Muscle strength, post-stroke \\
Age & Adult \\
\hline
\end{tabular}

\section{Literature search}

In the review of related literature, this article used data based on Science Direct, Google Scholar, EBSCO, and PMC. Articles relevant to the topic from January to September 2020. In literature search using Boolean operators "OR / AND." Keywords used in the search: ("ROM" AND "Stroke" OR "Post Stroke" AND "Muscle Strength" OR "Muscle Strength").

\section{Retrieval data}

The article used in doing this scoping review was related to the effect of ROM therapy on muscle strength in post-stroke patients and was published from January to September 2020. The literature used was in English. Participants in the reviewed articles were post-stroke patients. Non-English articles, case studies, reports were excluded.

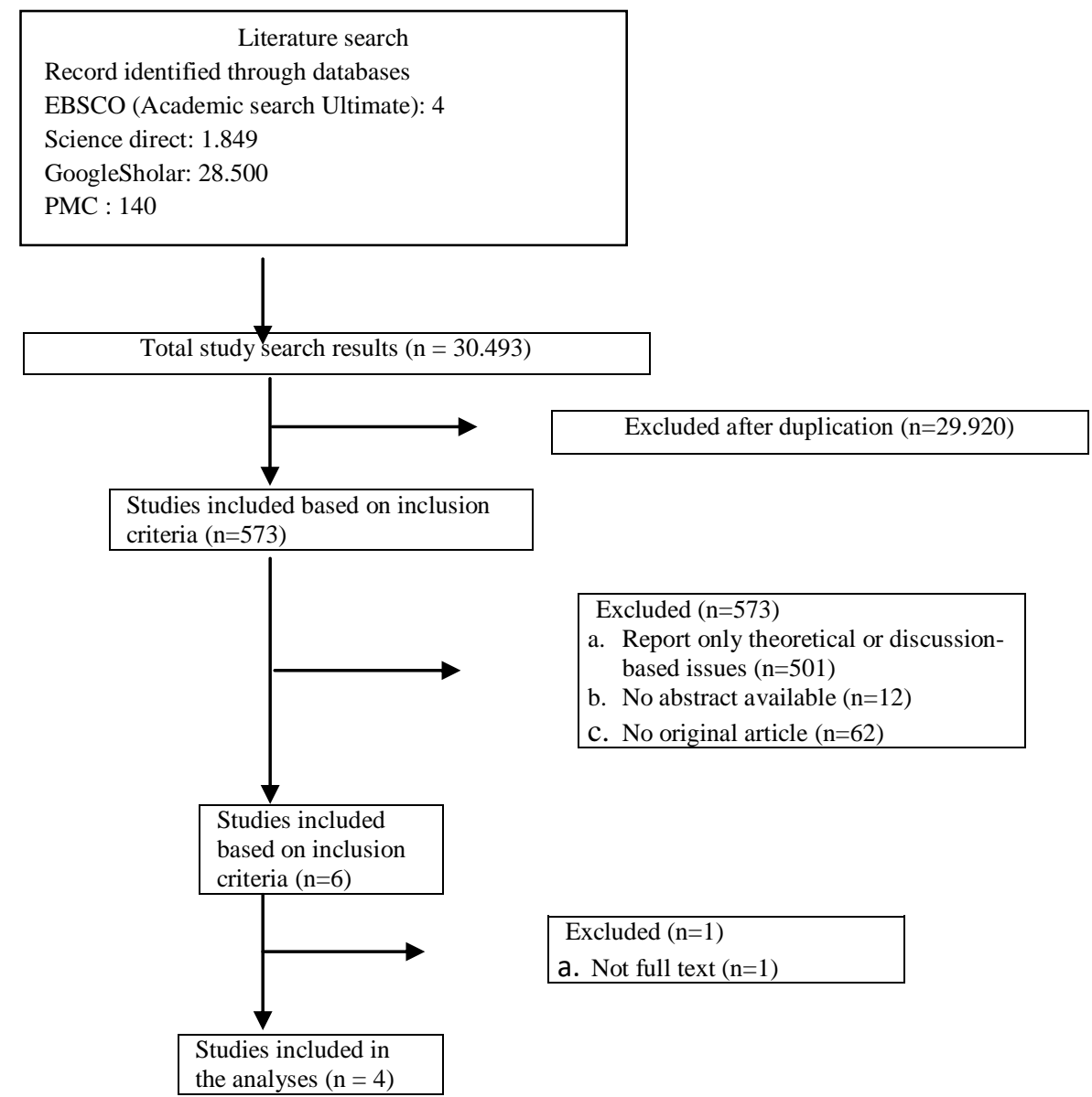

Figure 1. Diagram flow of study selection 


\section{RESULTS}

The characteristics of the data used in this study are presented in Table 2 . The effect of post stroke experienced by the respondent patient is the occurrence of muscle weakness so that it affects the patient's bodily function. These studies were conducted with an experimental design that tested ROM therapy on muscle strength after stroke.

Table 2.

Characteristic of studies

\begin{tabular}{|c|c|c|c|c|c|c|}
\hline No & Writer/year & Title & $\begin{array}{l}\text { Methods \& } \\
\text { Statistics } \\
\text { analysis }\end{array}$ & Results & Equation & Difference \\
\hline 1. & $\begin{array}{l}\text { Susanti, } \\
\text { Difran Nobel } \\
\text { Bistara. } \\
(2019)\end{array}$ & $\begin{array}{l}\text { The Effect } \\
\text { of Range } \\
\text { Motion on } \\
\text { Muscle } \\
\text { Strength in } \\
\text { Stroke } \\
\text { Patients. }\end{array}$ & $\begin{array}{l}\text { Method: } \\
\text { pre- } \\
\text { experimenta } \\
\text { 1 with One- } \\
\text { Group Pre- } \\
\text { Post Test } \\
\text { Design. } \\
\text { Region: } \\
\text { Bulak } \\
\text { Banteng } \\
\text { Health } \\
\text { Center, } \\
\text { Surabaya } \\
\text { Population: } \\
\text { 32 stroke } \\
\text { patients in } \\
\text { Bulak } \\
\text { Banteng } \\
\text { Public } \\
\text { Health } \\
\text { Center work } \\
\text { area } \\
\text { Measuring } \\
\text { instruments: } \\
\text { Muscle } \\
\text { strange } \\
\text { scale } \\
\text { Statistical } \\
\text { analysis: } \\
\text { different } \\
\text { test }\end{array}$ & $\begin{array}{l}\text { There was an } \\
\text { influence } \\
\text { between } \\
\text { Range of } \\
\text { Motion } \\
\text { (ROM) on } \\
\text { muscle } \\
\text { strength in } \\
\text { stroke } \\
\text { patients } \\
\text { because each } \\
\text { respondent } \\
\text { experienced } \\
\text { an increase } \\
\text { in the muscle } \\
\text { strength } \\
\text { scale after } \\
\text { ROM was } \\
\text { carried out } \\
\text { with P = } \\
0.000 \\
\text { P = 0.002 }\end{array}$ & $\begin{array}{l}\text { The } \\
\text { research } \\
\text { equation } \\
\text { was both } \\
\text { examinin } \\
\mathrm{g} \text { the } \\
\text { effect of } \\
\text { ROM } \\
\text { therapy } \\
\text { on } \\
\text { increased } \\
\text { muscle } \\
\text { strength } \\
\text { in stroke } \\
\text { patients. }\end{array}$ & $\begin{array}{l}\text { The difference } \\
\text { is more in the } \\
\text { technical } \\
\text { implementatio } \\
\mathrm{n} \text { where there } \\
\text { are four } \\
\text { months, one } \\
\text { month, four } \\
\text { weeks, and } \\
\text { some even } \\
\text { only three } \\
\text { days. }\end{array}$ \\
\hline 2 & $\begin{array}{l}\text { Chandra } \\
\text { Irawan, } \\
\text { Mardiyono, } \\
\text { Suharto, Aris } \\
\text { Santjaka } \\
\text { (2018) }\end{array}$ & $\begin{array}{l}\text { Combinatio } \\
\mathrm{n} \text { of } \\
\text { Hypnosis } \\
\text { Therapy and } \\
\text { Range of } \\
\text { Motion } \\
\text { Exercise on }\end{array}$ & $\begin{array}{l}\text { Design: } \\
\text { Quasi- } \\
\text { experiment } \\
\text { Setting: } \\
\text { Ward of the } \\
\text { General } \\
\text { Hospital of }\end{array}$ & $\begin{array}{l}\text { The } \\
\text { combination } \\
\text { of } \\
\text { hypnotherap } \\
\text { y and ROM } \\
\text { significantly } \\
\text { increased }\end{array}$ & $\begin{array}{l}\text { The } \\
\text { research } \\
\text { equation } \\
\text { was both } \\
\text { examinin } \\
\text { g the } \\
\text { effect of }\end{array}$ & $\begin{array}{l}\text { The difference } \\
\text { was more in } \\
\text { the technical } \\
\text { implementatio } \\
\mathrm{n} \text { where there } \\
\text { are four } \\
\text { months, one }\end{array}$ \\
\hline
\end{tabular}




\begin{tabular}{|c|c|c|c|c|c|c|}
\hline No & Writer/year & Title & $\begin{array}{l}\text { Methods \& } \\
\text { Statistics } \\
\text { analysis }\end{array}$ & Results & Equation & Difference \\
\hline & & $\begin{array}{l}\text { Upper- } \\
\text { Extremity } \\
\text { Muscle } \\
\text { Strength in } \\
\text { Patients } \\
\text { with Non- } \\
\text { Hemorrhagi } \\
\text { c Stroke }\end{array}$ & $\begin{array}{l}\text { Mataram } \\
\text { Population: } \\
\text { Thirty-two } \\
\text { samples } \\
\text { were } \\
\text { selected } \\
\text { using } \\
\text { simple } \\
\text { random } \\
\text { sampling } \\
\text { Measuring } \\
\text { instruments: } \\
\text { Muscle } \\
\text { strange } \\
\text { scale }\end{array}$ & $\begin{array}{l}\text { muscle } \\
\text { strength with } \\
\mathrm{p}=0.012\end{array}$ & $\begin{array}{l}\text { ROM } \\
\text { therapy } \\
\text { on } \\
\text { increased } \\
\text { muscle } \\
\text { strength } \\
\text { in stroke } \\
\text { patients }\end{array}$ & $\begin{array}{l}\text { month, four } \\
\text { weeks, and } \\
\text { some even } \\
\text { only three } \\
\text { days. Another } \\
\text { difference is } \\
\text { the } \\
\text { combination } \\
\text { with } \\
\text { hypnotherapy }\end{array}$ \\
\hline 3 & $\begin{array}{l}\text { Zahra-Sadat } \\
\text { Hosseini, } \\
\text { Hamid } \\
\text { Peyrovi, } \\
\text { Mahmoodrez } \\
\text { a Gohari } \\
\text { (2019) }\end{array}$ & $\begin{array}{l}\text { The Effect } \\
\text { of Early } \\
\text { Passive } \\
\text { Range of } \\
\text { Motion } \\
\text { Exercise on } \\
\text { Motor } \\
\text { Function of } \\
\text { People with } \\
\text { Stroke: A } \\
\text { Randomize } \\
\text { d Controlled } \\
\text { Trial" }\end{array}$ & $\begin{array}{l}\text { design: } \\
\text { RCT } \\
\text { Setting: } \\
\text { Poursina } \\
\text { teaching } \\
\text { hospital in } \\
\text { the city of } \\
\text { Rasht, Iran } \\
\text { Population: } \\
\text { patients } \\
\text { with first } \\
\text { ischemic } \\
\text { stroke } \\
\text { Measuring } \\
\text { tool: Oxford } \\
\text { scale } \\
\text { Statistical } \\
\text { analyzes: } \\
\text { paired- } \\
\text { sample t- } \\
\text { test and } \\
\text { independent } \\
\text { t-test }\end{array}$ & $\begin{array}{l}\text { The } \\
\text { experimental } \\
\text { group } \\
\text { intervention } \\
\text { led to a } \\
\text { significant } \\
\text { motor } \\
\text { function } \\
\text { improvement } \\
\text { between the } \\
\text { first and third } \\
\text { months in } \\
\text { both upper } \\
\text { and lower } \\
\text { extremities. } \\
\text { In the control } \\
\text { group, } \\
\text { improvement } \\
\text { s were } \\
\text { observed } \\
\text { only in upper } \\
\text { limb muscle } \\
\text { strength at } \\
\text { the first and } \\
\text { third months } \\
\text { compared } \\
\text { with the pre- } \\
\text { intervention } \\
\text { measure with } \\
\text { p = 0.004. }\end{array}$ & $\begin{array}{l}\text { The } \\
\text { research } \\
\text { equation } \\
\text { was } \\
\text { examinin } \\
\mathrm{g} \text { the } \\
\text { effect of } \\
\text { ROM } \\
\text { therapy } \\
\text { on } \\
\text { increased } \\
\text { muscle } \\
\text { strength } \\
\text { in stroke } \\
\text { patients }\end{array}$ & $\begin{array}{l}\text { The difference } \\
\text { is more in the } \\
\text { technical } \\
\text { implementatio } \\
\mathrm{n} \text { where there } \\
\text { are four } \\
\text { months, one } \\
\text { month, four } \\
\text { weeks, and } \\
\text { some even } \\
\text { only three } \\
\text { days. ROM } \\
\text { used is passive } \\
\text { ROM }\end{array}$ \\
\hline
\end{tabular}




\begin{tabular}{|c|c|c|c|c|c|c|}
\hline No & Writer/year & Title & $\begin{array}{c}\text { Methods \& } \\
\text { Statistics } \\
\text { analysis }\end{array}$ & Results & Equation & Difference \\
\hline 4 & $\begin{array}{l}\text { Hyun Ju } \\
\text { Kim, yaelim } \\
\text { lee, Kyeong- } \\
\text { yae SoHng, } \\
\text { (2014) }\end{array}$ & $\begin{array}{l}\text { Effects of } \\
\text { Bilateral } \\
\text { Passive } \\
\text { Range of } \\
\text { Motion } \\
\text { Exercise on } \\
\text { the Function } \\
\text { of Upper } \\
\text { Extremities } \\
\text { and } \\
\text { Activities of } \\
\text { Daily } \\
\text { Living in } \\
\text { Patients } \\
\text { with Acute } \\
\text { Stroke }\end{array}$ & $\begin{array}{l}\text { Design: } \\
\text { Quasi- } \\
\text { experiment } \\
\text { Settings: } \\
\text { NSICU } \\
\text { Population: } \\
\text { patients } \\
\text { who were } \\
\text { hospitalized } \\
\text { in the } \\
\text { NSICU } \\
\text { Statistics: } \\
\text { ANOVA }\end{array}$ & $\begin{array}{l}\text { The results } \\
\text { showed } \\
\text { significant } \\
\text { improvement } \\
\text { s in range of } \\
\text { motion, } \\
\text { upper limb } \\
\text { function, and } \\
\text { daily living } \\
\text { activities } \\
\text { compared to } \\
\text { the control } \\
\text { group with p } \\
=0.001 .\end{array}$ & $\begin{array}{l}\text { The } \\
\text { research } \\
\text { equation } \\
\text { is } \\
\text { examinin } \\
\mathrm{g} \text { the } \\
\text { effect of } \\
\text { ROM } \\
\text { therapy } \\
\text { on } \\
\text { increased } \\
\text { muscle } \\
\text { strength } \\
\text { in stroke } \\
\text { patients. }\end{array}$ & $\begin{array}{l}\text { The difference } \\
\text { is more in the } \\
\text { technical } \\
\text { implementatio } \\
\mathrm{n} \text { where there } \\
\text { are four } \\
\text { months, one } \\
\text { month, four } \\
\text { weeks, and } \\
\text { some even } \\
\text { only three } \\
\text { days. } \\
\text { Combined } \\
\text { with ADL }\end{array}$ \\
\hline
\end{tabular}

\section{DISCUSSION}

The number of journals for this review consisted of 4 articles, all of which discussed ROM therapy's application to increase muscle strength in post-stroke patients. The results of each of these articles indicate that ROM therapy has been able to help improve muscle strength in post-stroke patients. The similarity of each of these articles is ROM therapy provision to increase muscle strength in stroke patients. The difference is more in the technical implementation where there are four months, one month, four weeks, and some even only three days. Another difference is that some used ROM only, some used passive ROM, some combined ROM with hypnotherapy, and some combined ADL exercises.

Susanti, Difran Nobel Bistara. (2019), explained that the study's implementation lasted for one month with ROM therapy carried out every day, with a duration based on SOP for 10-15 minutes. The study results found an influence between ROM on muscle strength in stroke patients because each respondent experienced an increase in the muscle strength scale after ROM was performed. Increased muscle strength scale from a scale of 3 to a scale of 4 (Susanti et al., 2019).

Chandra Irawan, Mardiyono, Suharto, Aris Santjaka (2018) explained that ROM therapy was carried out for three days with a frequency of 2 times a day. The study results found that the combination of hypnotherapy and ROM significantly increased muscle strength. These results also showed that ROM therapy influenced muscle ability, which would influence the ability to mobilize patients after stroke (Irawan et al., 2018).

Another study conducted by Zahra-Sadat Hosseini, Hamid Peyrovi, Mahmoodreza Gohari (2019), shown in the acute phase, intervention in the experimental group led to significant improvement in motor function between the first and third months in both upper and lower extremities. In the control group, improvements were observed only in upper limb muscle strength at the first and third months compared with the pre-intervention measures. The most significant increases were observed at intervals from base to one month in the upper limb, and 
basis to month one and month to month to month three in the lower limb (Zahra-Sadat Hosseini, Hamid Peyrovi, 2018).

According to Hyun Ju Kim, yaelim lee, Kyeong-yae SoHng, (2014), the implementation of ROM was four weeks, wherein one week it was carried out for five days and in one day twice. The results found that the experimental group showed a significant reduction in upper limb edema compared to the control group. It also showed significant improvements in range of motion, upper limb function, and daily living activities compared to the control group. [Conclusion] The series of passive motion exercises at an early stage can improve upper limb function and daily living activities in patients with acute stroke (Kim et al., 2014).

ROM influences the respondent's range of motion if done twice a day in six days and 10-15 minutes in one exercise. ROM is the joints' movement that allows muscle contraction and movement, both passively and actively. This result showed an influence between ROM on muscle strength in stroke patients because each respondent experienced an increase in the muscle strength scale after ROM was performed.

The contraction mechanism can increase smooth muscle in the extremities. Passive ROM exercises can cause stimulation, thereby increasing the activation of chemical, neuromuscular, and muscular. Smooth strength in the extremities contains actin and myosin filaments, which have chemical properties and interact with one another. The interaction process is activated by calcium ions and adeno triphosphate (ATP), broken down into adeno-diphosphate (ADP) to provide energy for limb muscle contraception. Neuromuscular stimulation will increase the limb muscle nerve fibers' stimulation, especially the parasympathetic nerves, which stimulate acetylcholine production, resulting in contractions. The mechanism through the musculus, especially the extremities' smooth muscle, will increase metabolism in the mitochondria to produce ATP, which is utilized by the extremities' smooth muscle as energy for contraction and increase the smooth muscle tone of the extremities. To determine the effect of passive ROM exercises on increasing muscle strength in stroke patients with hemiparesis. (Anggriani et al., 2018)

\section{CONCLUSION}

The use of ROM therapy can increase muscle strength in post-stroke patients, so that this increased muscle strength will provide an increase in the ability to mobilize. ROM therapy can also be used as an intervention in clinical areas.

\section{REFERENCES}

Anggriani, A., Zulkarnain, Z., Sulaiman, S., \& Gunawan, R. (2018). Pengaruh ROM (Range of Motion) Terhadap Kekuatan Otot Ekstremitas Pada Pasien Stroke Non Hemoragic. Jurnal Riset Hesti Medan Akper Kesdam I/BB Medan, 3(2), 64. https://doi.org/10.34008/jurhesti.v3i2.46

Asmadi. (2012). Teknik proseduralkeperawatan: konsep dan aplikasi kebutuhan dasar klien. Salemba Medika.

Bakara, D. M., \& Warsito, S. (2016). Latihan Range of Motion (Rom) Pasif Terhadap Rentang Sendi Pasien Pasca Stroke. Idea Nursing Journal, 7(2), 12-18.

Garrison, S. . (2003). Handbook of physical medicine and rehabilitation. Edisi II. Lippincott Williams \& Wilkins. 
Husna, M., Kusworini, \& Wulansari, D. A. (2015). Correlation Between Leukocyte Count When Admitted in Emergency Room ( Er ). Husna, et Al. Correlation Between Leukocyte Count, 46-51.

Irawan, C., Mardiyono, M., Suharto, S., \& Santjaka, A. (2018). Combination of Hypnosis Therapy and Range of Motion Exercise on Upper-Extremity Muscle Strength in Patients With Non-Hemorraghic Stroke. Belitung Nursing Journal, 4(1), 104-111. https://doi.org/10.33546/bnj.347

Jateng, D. (n.d.). Profil Kesehatan Provinsi Jawa Tengah Tahun 2018.

Kemenkes RI. (2018). Peningkatan Gaya Hidup Sehat dengan perilaku “CERDIK” (p. 10).

Kementerian Kesehatan RI Badan Penelitian dan Pengembangan. (2018). Hasil Utama Riset Kesehatan Dasar. Kementrian Kesehatan Republik Indonesia, 1-100. https://doi.org/1 Desember 2013

Kim, H. J., Lee, Y., \& Sohng, K. Y. (2014). Effects of bilateral passive range of motion exercise on the function of upper extremities and activities of daily living in patients with acute stroke. Journal of Physical Therapy Science, 26(1), 149-156. https://doi.org/10.1589/jpts.26.149

Kristiani, R. B. (2017). Pengaruh Range of Motion Exercise terhadap Kekuatan Otot Pasien Stroke di Wilayah Puskesmas Sidotopo Surabaya. Jurnal Ners LENTERA, 5(2), 169177.

National E-Health Transition Authority. (2012). Australian Safety and Quality Goals for Health Care. 10 February, 1-9.

Nurbaeni, J., Sudiana, I., \& Harmayetty. (2010). Range of Motion Exercise of Arms Increases the Mucle Strength for Post Stroke Patients. 5, 15-20.

Profil Kesehatan Kota Semarang. (2016). Profil Kesehatan Kota Semarang 2015. Dinkes.Semarang.Go.Id, 1-104.

Susanti, S., Susanti, S., \& BIstara, D. N. (2019). Pengaruh Range of Motion (ROM) terhadap Kekuatan Otot pada Pasien Stroke. Jurnal Kesehatan Vokasional, 4(2), 112. https://doi.org/10.22146/jkesvo.44497

Zahra-Sadat Hosseini , Hamid Peyrovi, M. G. (2018). The Effect of Early Passive Range of Motion Exercise on Motor Function of People with Stroke: a Randomized Controlled Trial. Journal of Caring Sciences, 7(1), 35-40. https://doi.org/10.15171/jcs.2019.006 